\title{
Climate Change: A Comparison Of Market-Based Instruments From A South African Perspective
}

Suren Pillay, South African Revenue Service (SARS), South Africa Pieter W Buys, North-West University, South Africa

\begin{abstract}
This article aims to consider the relevancy of (i) cap-and-trade schemes and (ii) carbon tax schemes in a developing economy context. Even though both schemes have a common goal of reducing greenhouse gas emissions, they operate very differently, each with their own set of advantages and disadvantages. Sustainable developments comprise various elements categorised in three primary dimensions - environmental, economic and social. The objective of reducing greenhouse gases via the implementation of carbon tax or cap-and-trade schemes primarily addresses the environmental dimension of sustainable development. Notwithstanding the aforementioned, the impact of both schemes on the economically sustainable development, including industry competitiveness and growth, still has to be determined. In South Africa, the National Treasury made a decision to implement carbon tax as opposed to cap-and-trade schemes. In this article, the reasoning behind their decision in favour of carbon tax in the South African context is critically considered, firstly by evaluating the key characteristics between capand-trade and carbon tax schemes and secondly by considering the effectiveness hereof in the global context. It was found primary reason behind the favourable consideration of carbon tax was the fact the implementation thereof would be 'simpler' using the existing taxation systems, whereas cap-and-trade would require the implementation of sophisticated mechanisms that may not provide the optimum benefit in a developing economy context.
\end{abstract}

Keywords: Climate Change; Carbon Taxation; Cap-And-Trade Scheme; Greenhouse Gas Emissions; Sustainable Development

\section{INTRODUCTION}

Background

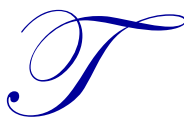

he issue of global warming in recent years has been at the forefront of not only the scientific community, but also of various governmental institutions (Ren \& Lin, 2001). Many scientists are of the opinion that higher concentrations of greenhouse gas emissions, such as carbon dioxide and methane, can negatively affect our climate (Sathiendrakumar, 2003) and that if the atmospheric concentrations of these greenhouse gases continue to rise, the global climate will become increasingly warmer (Yusuf et al., 2012; Ren \& Lin, 2001). Shepherd (2012:1) is in agreement herewith when saying that the climate change currently being experienced is due to an increase in greenhouse gas emissions that arise from human activities, such as the burning of fossil fuels, agriculture and deforestation. Spectral calculations also confirm that water vapour accounts for approximately $87 \%$ of the greenhouse effect and a doubling of the current level of carbon dioxide emissions would result in a rise in global temperatures of $0.51^{\circ} \mathrm{C}$ without water feedback (Ollila, 2012). In South Africa, the level of carbon emissions per unit of economic output was nearly three times the average set by the Organisation for Economic Co-operation and Development (OECD) (Goldblatt \& Davies, 2002). 
Governments considering strategies for lowering carbon emissions ordinarily have two basic approaches to consider, namely i) a cap-and-trade scheme that reduces emissions by limiting the quantity of carbon dioxide that can be emitted and then allocating emissions permits that are tradable, or ii) introducing a carbon tax scheme that effectively raises the price of fossil fuels based on their carbon content (Anon, 2012). The cap-and-trade approach has its foundation in the United Nations Framework Convention on Climate Change (UNFCCC) that was established with the goal of reducing the concentration of greenhouse gases in the atmosphere, to which South Africa became a signatory in August 1997 (UNFCCC, 2004). In a cap-and-trade scheme, a governmental organisation typically issues a license (or permit) to pollute to major industries with the entity then being in position to trade these permits with another entity who might make 'equivalent' changes more cost effectively (Gilbertson \& Reyes, 2009). This is the approach underlying most emission trading schemes with the underlying theory that the available supply of permits will be slowly reduced, so that the market retains its value while at the same time forcing a decrease in the overall level of greenhouse gas emissions (Gilbertson \& Reyes 2009). On the other hand, carbon $\operatorname{tax}$ is in essence an excise tax on the producers of raw fossil fuels based on the relative carbon content of those fuels (OECD, 1997). The objective of carbon tax is therefore to control the problem of global warming caused by increasing concentrations of greenhouse gases, which then, per se, include carbon (Pearson \& Smith, 1991). The impact of carbon tax is ordinarily determined by using the energy demand function that considers the price elasticity of energy (Yamaguchi, 2007). According to SBS (2012), carbon tax schemes have been implemented in many countries around the world, including Denmark, Finland, Ireland, the Netherlands, Norway, Slovenia, Sweden, Switzerland, the United Kingdom, Canada, India, Costa Rica and China.

\section{Sustainable development}

From the above it is evident that both cap-and-trade schemes and carbon tax schemes intended to effect reductions in greenhouse gas emissions in order to contribute to sustainable development. According to Mohammed (2011), sustainable development has been defined as that which is required to harmonise the fulfilment of human needs with the protection of the natural environment so that these needs can be met not only in the present, but also in the indefinite future. Sustainable development comprises various elements categorised into three primary dimensions, namely environmental, economic and social, which in essence is the so-called triple bottom line, which has been defined as the balance within the concept of sustainability (Cronje \& Chenga, 2009; Anon, 2006; Newport et al., 2003):

- $\quad$ The economic dimension of sustainability is important as critical issues such as costs associated with environmental pollution, constraints on economic growth and the destruction of non-renewable resources are addressed by this area of sustainable development.

- With regard to social sustainability, it is suggested that the social dimension of sustainable development encompasses the transformation, and perpetual improvement of the livelihoods of human beings within a specific social context.

- In terms of environmental sustainability, clean air and water, reduced toxic emissions and reducing household waste as well as conserving natural resources are among the important environmental policy objectives that most OECD governments have been pursuing over the past thirty years.

\section{The South African context}

In terms of related carbon emission developments in South Africa, the National Treasury published a discussion document considering the economic merits for introducing a carbon tax in South Africa in December 2010 (National Treasury, 2010). This elicited 79 stakeholder responses, with a more detailed policy document containing the design of the carbon tax anticipated to be released in due course (WWF, 2012).

However, prior to this, on 1 September 2010, a carbon emission tax on the sale of new passenger motor vehicles in South Africa was implemented, which added a tax of R75 for every gram of carbon dioxide per kilometre it emits over the $120 \mathrm{~g} / \mathrm{km}$ (NAAMSA, 2011; Shirley, 2010). These vehicles are taxed on carbon dioxide emissions above $120 \mathrm{~g} / \mathrm{km}$ at a fixed rate of ZAR75 per g/km. Therefore, if a new passenger car emits $200 \mathrm{~g} / \mathrm{km}$ of carbon dioxide, it will be taxed on the $80 \mathrm{~g} / \mathrm{km}$ emitted above the $120 \mathrm{~g} / \mathrm{km}$ threshold. At the suggested flat rate of ZAR75 per g/km, such a vehicle will attract carbon tax of around ZAR 6000 (Finnern, 2010). In terms of the 
industry's contribution to sustainable development in the region, it contributed approximately $7.5 \%$ to the country's GDP in 2008 (SAI, 2008a). Therefore, due to its importance to the South African economy, the impact of hereof is expected to be significant. The National Association of Automobile Manufacturers of South Africa (NAAMSA) suggested that carbon tax will inflate vehicle prices by as much as $2 \%$, which may lower sales volumes and could negatively impact vehicle industry employment levels (Anon, 2010).

\section{PROBLEM STATEMENT AND OBJECTIVES}

Following from the above, the question may be asked as to the total impact of the implementation of carbon tax as an environmental policy, not only in the context of the South African vehicle industry, but also in the context of the broader economy. In light hereof, the primary research question under consideration could be formulated as follows:

- Is the carbon tax mechanism the most appropriate mechanism to reduce greenhouse gas emissions within the South African developing economy context, seen in the light of global experiences?

In consideration hereof, this paper aims to examine firstly the distinguishing natures of i) cap-and-trade schemes and ii) carbon tax schemes, and secondly to provide an evaluation of the decision made by the National Treasury to implement carbon tax in South Africa. The research is based on an analytical literature study research methodology and utilises a three-step approach in considering whether carbon tax is the most appropriate mechanism to reduce greenhouse gas emissions in South Africa. Firstly, the key distinguishing features between the carbon tax and cap-and-trade mechanisms are analysed, secondly, the effectiveness of these scheme are evaluated based on global experiences and thirdly an evaluation of the National Treasury's case for carbon tax is provided.

\section{KEY FEATURES OF CAP-AND-TRADE AND CARBON TAX SCHEMES}

\section{Introduction}

According to Goldblatt (2010a), the primary distinguishing features of cap-and-trade and carbon tax schemes are typically threefold, namely:

- In terms of carbon pricing, carbon tax offers some level of certainty as the price is fixed; whereas with a cap-and-trade approach, the carbon price is uncertain and is subject to market volatility.

- In terms of achieving quantitative limits of carbon emissions, the cap-and-trade approach appears to be able to accomplish this more effectively than carbon tax as emissions are capped and therefore provide some level of certainty of the environmental outcome.

- In terms of administrative costs, the carbon tax approach may be seen as a more efficient option as its implementation can be executed within the infrastructure of the existing tax administration, whereas the cap-and-trade approach may require the creation of a new institution to implement a trading scheme.

The distinctive characteristics of these two approaches are discussed in more detail below.

\section{Cap-and-trade schemes}

The foundation of the cap-and-trade methodology originated with C Boyden Gray who talked about cleaning up the environment by letting people buy and sell rights to pollute (Smithsonian, 2009). This concept was initially termed emissions trading, but was subsequently changed to cap and trade. In a cap-and-trade scheme, quantitative limits are set on the time path for greenhouse gas emissions of different countries with these countries then administering these limits in their own fashion. These schemes typically allow for the transfer of emission allowances between the different countries under the Kyoto Protocol (Noordhaus, 2007). With regard to cap- andtrade schemes in South Africa, it should be noted that South Africa signed the protocol in 2002, and even though it has no commitment to cap emissions, it is involved in Clean Development Mechanism (CDM) projects (DEAT 2010). Some of the key (negative) characteristics of cap-and-trade schemes include the following: 
- $\quad$ There may be initial over-allocation permits to governments or companies resulting in no required behavioural change by companies regarding carbon emissions (Gilbertson \& Reyes, 2009).

- $\quad$ In some instances, producers may be able to transfer abatement costs to consumers and increase its prices without consideration of the true purposes of the scheme (Gilbertson \& Reyes, 2009).

- $\quad$ There are major administrative complexities related to cap-and-trade schemes together with uncertainties with regard to the actual economic costs to business (National Treasury, 2010).

A further issue is the concept of carbon leakage, which is said to occur when there is an increase in greenhouse gas emissions in one country as a result of emission reductions in another country that has stricter climate change policies (CLC, 2010). The results of studies conducted on the effects of the Kyoto Protocol have shown carbon leakage to be in the range of 5 to $20 \%$ using static Computable General Equilibrium models, which differs from the opinion of researchers who say, in practice, carbon leakage is not substantial due to transport costs and local market conditions (Barker et al., 2007). The principles of the cap-and-trade approach, however, have indicated some positive aspects, including the following:

- $\quad$ Trade schemes implemented in air pollution programmes in the United States reported a strong positive effect on reducing emissions (Tietenburg, 2003).

- $\quad$ The performance of cap-and-trade schemes in the field of improving environmental sustainability was assessed using a simulation model at the University of Saskatchewan, where it was revealed that it decreased carbon dioxide emissions and increased environmental and economic sustainability (Belcher et al., 2003).

\section{Carbon tax}

Carbon tax, which was first introduced in Europe in the early 1990s, has been widely advocated as a means for reducing such emissions to address anthropogenic climate change (Clarke, 2011). In principle, carbon taxes are levied at the same specific rate on all emissions, irrespective of their source. Since carbon emissions have a proportional relationship to fossil fuel usage, this could be charged directly on emissions of fossil fuels such petrol, gas and coal (IMF, 2008). In addition to the advantages of price certainty and lower administrative costs, carbon tax offers the advantage of economy-wide application in terms of coverage in comparison to cap-and-trade schemes that ordinarily only cover high emitters in the initial phases (Goldblatt, 2010a). Another advantage is that pricing systems such as carbon tax are less susceptible to corruption than quantity type systems, with this being demonstrated frequently at international trade interventions when quotas are compared to tariffs (Noordhaus, 2007). A further significant advantage, according to Pope and Owen (2009), is the suggestion that it would provide a more stable revenue base over time. They propose (within the Australian context) that it may generate around A $\$ 11.5$ billion per annum, subject to various treasury assumptions (Pope \& Owen, 2009).

In terms of disadvantages, carbon tax schemes do not ensure quantifiable, emission reductions (National Treasury, 2010). This assumption is supported by the simulation model developed at the University of Saskatchewan, which revealed that carbon tax had no significant effect on carbon dioxide emissions or environmental sustainability, but may rather decrease economic sustainability (Belcher et al., 2003). Another possible significant disadvantage is the pricing of carbon. The social cost of carbon has been defined as the monetary damage done by emitting one more ton of carbon at some point in time. Using quantitative modelling, a marginal cost of $£ 100$ per ton of carbon has been noted in the United Kingdom (Pearce, 2003). Ideally, the carbon tax price should be priced to cover the marginal cost per ton of carbon, with the resultant question then being whether the carbon tax price accurately reflects the monetary damage caused by an additional ton of carbon?

\section{EVALUATION OF THE EFFECTIVENESS OF SUCH SCHEMES}

\section{Cap-and-trade schemes}

In terms of cap and trade, the European Union Environmental Trading Scheme (EU ETS) is the world's largest emissions permit market to date and is organised into distinctive periods referred to as 'phases', with Phase I between 2005 and 2007 and Phase II between 2008 and 2012 (Hintermann, 2012). In terms of the effectiveness 
hereof in reducing greenhouse gas emissions, a sample study of 2101 European firms subject to the EU ETS revealed that it led to reductions in emissions in both phases (Abrell et al., 2011).

In respect of Phase I, an analysis of carbon dioxide emissions by countries subject to the EU ETS (Table 1 below) found an overall net increase of $1.88 \%$ in GHG emissions, with 11 out of the 24 countries recording decreases in their carbon emissions.

Table 1: Phase I: Emissions of EU ETS countries (tons of carbon)

\begin{tabular}{|c|c|c|c|c|}
\hline Country & 2005 & 2006 & 2007 & \% change \\
\hline Austria & $33,372,826$ & 32382804 & 31751165 & -4.86 \\
\hline Belgium & $55,363,223$ & 54775314 & 52795318 & -4.64 \\
\hline Cyprus & $5,078,866$ & 5259273 & 5396164 & 6.25 \\
\hline Czech Republic & $82,454,618$ & 83624953 & 87834758 & 6.52 \\
\hline Germany & $474,990,760$ & 478016581 & 487004055 & 2.53 \\
\hline Denmark & $26,475,718$ & 34199588 & 29407355 & 11.07 \\
\hline Estonia & $12,621,817$ & 12109278 & 15329931 & 21.46 \\
\hline Spain & $183,626,981$ & 179711225 & 186495894 & 1.56 \\
\hline Finland & $33,099,625$ & 44621411 & 42541327 & 28.53 \\
\hline France & $131,263,787$ & 126979048 & 126634806 & -3.53 \\
\hline Greece & $71,267,736$ & 69965145 & 72717006 & 2.03 \\
\hline Hungary & $26,161,627$ & 25845891 & 26835478 & 2.58 \\
\hline Ireland & $22,441,000$ & 21705328 & 21246117 & -5.32 \\
\hline Italy & $225,989,357$ & 227439408 & 226368773 & 0.17 \\
\hline Lithuania & $6,603,869$ & 6516911 & 5998744 & -9.16 \\
\hline Luxembourg & $2,603,349$ & 2712972 & 2567231 & -1.39 \\
\hline Latvia & $2,854,481$ & 2940680 & 2849203 & -0.18 \\
\hline Netherlands & $80,351,288$ & 76701184 & 79874658 & -0.59 \\
\hline Poland & $203,149,562$ & 209616285 & 209601993 & 3.18 \\
\hline Portugal & $36,425,915$ & 33083871 & 31183076 & -14.39 \\
\hline Sweden & $19,381,623$ & 19884147 & 15348209 & -20.81 \\
\hline Slovenia & $8,720,548$ & 8842181 & 9048633 & 3.76 \\
\hline Slovakia & $25,231,767$ & 25543239 & 24516830 & -2.83 \\
\hline United Kingdom & $242,513,099$ & 251159840 & 256581160 & 5.80 \\
\hline Total & $2,012,043,453$ & 2033636557 & 2049927884 & 1.88 \\
\hline
\end{tabular}

Source: Anon (2008b)

In respect of Phase II (Table 2 below), all the countries reported reductions in carbon emissions, with an overall reduction of $7.2 \%$

From a review of the above tables it is clear that the EU ETS was more effective in Phase II than in Phase I. It is, however, argued that Phase I not only established a carbon price for material sectors of economic activity in Europe, but also established the necessary trading infrastructure (Convery et al., 2008). Furthermore, during Phase I, the permits allocated were also found to be consistently higher than the actual verified emissions taking place in the EU ETS countries (Gilbertson \& Reyes, 2009). 
Table 2: Phase II: Emissions of EU ETS countries (tons of carbon)

\begin{tabular}{|l|c|c|c|}
\hline \multicolumn{1}{|c|}{ Country } & $\mathbf{2 0 0 8}$ & $\mathbf{2 0 0 9}$ & \% change \\
\hline Austria & 68232000 & 62313000 & -8.67 \\
\hline Belgium & 104865000 & 103593000 & -1.21 \\
\hline Cyprus & 8555000 & 8199000 & -4.16 \\
\hline Czech Republic & 116952000 & 108121000 & -6.52 \\
\hline Germany & 786652000 & 734599000 & -2.46 \\
\hline Denmark & 46850000 & 45698000 & -13.23 \\
\hline Estonia & 18383000 & 15951000 & -12.47 \\
\hline Spain & 329286000 & 288230000 & -4.48 \\
\hline Finland & 56083000 & 53568000 & -3.62 \\
\hline France & 376993000 & 363356000 & -2.96 \\
\hline Greece & 97817000 & 94917000 & -10.94 \\
\hline Hungary & 54653000 & 48676000 & -4.06 \\
\hline Ireland & 43406000 & 41642000 & -10.40 \\
\hline Italy & 447367000 & 400836000 & -15.15 \\
\hline Lithuania & 15130000 & 12838000 & -4.85 \\
\hline Luxembourg & 10660000 & 10143000 & -12.37 \\
\hline Latvia & 7591000 & 6652000 & -2.41 \\
\hline Netherlands & 173845000 & 169650000 & -5.43 \\
\hline Poland & 316059000 & 298905000 & -1.64 \\
\hline Portugal & 58357000 & 57400000 & -10.92 \\
\hline Sweden & 49105000 & 43744000 & -10.88 \\
\hline Slovenia & 17158000 & 15291000 & -9.76 \\
\hline Slovakia & 37557000 & 33890000 & -9.13 \\
\hline United Kingdom & 522247000 & 474579000 & -7.20 \\
\hline Total & 3763803000 & 3492791000 & \\
\hline Source & & & \\
\hline
\end{tabular}

Source: UN (2011)

\section{Carbon tax}

Various studies around the world have been conducted using simulations to determine the estimated impact of carbon tax on greenhouse gas emissions, such as the following:

- In a study estimating the impact of carbon tax on greenhouse gas emissions in Nepal using an energy system model, it was confirmed that the introduction of carbon tax would result in an estimated reduction of $12 \%$ under certain conditions (Shakya et al., 2012).

- $\quad$ A study estimating the effect of policy instruments such as carbon tax in Austria on the passenger motor vehicles confirmed that policy measures may demonstrate an effective reduction in GHG emissions (Kloess \& Muller, 2011).

- In terms of the actual effectiveness of the tax in reducing greenhouse gases, studies conducted in Norway, one of the first countries to introduce carbon tax in 1991, revealed that carbon emissions increased by $19 \%$ from 1990 to 1999 as opposed to a GDP growth of 35\% in the same period, which pointed to an overall reduction in average emission per unit GDP of 12\% (Bruvoll \& Larson, 2004).

- $\quad$ In Sweden, an ex-post evaluation of the implementation of carbon tax for the years 1992 to 1995 shows mixed results of the effect of the carbon tax on carbon emissions according to different industries affected by the tax, and also revealed that even though the services sector, household and transport sectors reported no change in emission levels, there was a positive effect on carbon emission levels (Bohlin, 1998).

- In both the Netherlands and Denmark, tax exemptions were provided for the manufacturing industry and related energy intensive industries, and this reduced the mitigating effects of carbon tax in these countries (Lin \& Li, 2012).

- $\quad$ Carbon tax on passenger motor vehicles was introduced in Ireland in 2008, and a study estimating the effect of the tax on greenhouse gas emissions revealed that it should result in a decline in greenhouse gas emissions of 0.2 milllions tons of carbon by 2015 (Hennessy \& Toll, 2011). 
- An analysis of the implementation of a potential carbon tax in Washington using a Carbon Tax Analysis Model revealed that a carbon tax at US\$30 per metric ton of carbon dioxide lowers GHG emissions by $8.4 \%$ (Keibun, 2011).

\section{Effects of cap-and-trade and carbon tax on industry}

In terms of the economic effect of cap-and-trade schemes on profit, employment and value added, a firmbased study of the EU ETS revealed that in Phase I and the beginning of Phase II, the EU ETS did not materially affect profits, employment and value added (Abrell et al., 2011). An interim analysis of Phase I of the EU ETS confirms that the first phase had little impact on industry competitiveness (Convery et al., 2008). Table 3 below summarises the GDP per capita information (adjusted for current prices) for each EU ETS country in the period 2005 to 2009. With the exception of the United Kingdom, all countries reported a real increase in economic growth during the period, with the aggregate economic output growing in real terms by $21 \%$. This mitigates any argument that cap-and-trade schemes will result in decreased profits and growth for companies and industries alike.

Table 3: EU ETS countries: GDP per capita (US dollars at current prices)

\begin{tabular}{|l|c|c|c|c|c|c|}
\hline \multicolumn{1}{|c|}{ Country } & $\mathbf{2 0 0 5}$ & $\mathbf{2 0 0 6}$ & $\mathbf{2 0 0 7}$ & $\mathbf{2 0 0 8}$ & $\mathbf{2 0 0 9}$ & \% change \\
\hline Austria & 37048 & 39278 & 45133 & 49650 & 45614 & 23 \\
\hline Belgium & 36225 & 38167 & 43586 & 47822 & 44356 & 22 \\
\hline Cyprus & 22298 & 23876 & 27686 & 31693 & 29277 & 31 \\
\hline Czech Republic & 12726 & 14463 & 17499 & 21723 & 18789 & 48 \\
\hline Denmark & 47546 & 50412 & 56941 & 62115 & 55915 & 18 \\
\hline Estonia & 10330 & 12506 & 16375 & 17773 & 14337 & 39 \\
\hline Finland & 37302 & 39460 & 46523 & 51153 & 45062 & 21 \\
\hline France & 34002 & 35669 & 40586 & 44245 & 40773 & 20 \\
\hline Germany & 33514 & 35169 & 40281 & 43937 & 40029 & 19 \\
\hline Greece & 21468 & 23357 & 27088 & 30216 & 28411 & 32 \\
\hline Hungary & 10937 & 11181 & 13553 & 15390 & 12660 & 16 \\
\hline Ireland & 48888 & 52922 & 60578 & 60570 & 50564 & 3 \\
\hline Italy & 30299 & 31539 & 35569 & 38344 & 35041 & 16 \\
\hline Latvia & 6913 & 8658 & 12557 & 14729 & 11433 & 65 \\
\hline Lithuania & 7641 & 8900 & 11636 & 14153 & 11075 & 45 \\
\hline Luxembourg & 82370 & 91395 & 107863 & 118673 & 104384 & 27 \\
\hline Netherlands & 39157 & 41378 & 47591 & 52766 & 47915 & 22 \\
\hline Poland & 7963 & 8949 & 11132 & 13852 & 11256 & 41 \\
\hline Portugal & 18132 & 19008 & 21846 & 23689 & 21976 & 21 \\
\hline Slovakia & 8844 & 10290 & 13803 & 17348 & 16026 & 81 \\
\hline Slovenia & 17840 & 19406 & 23507 & 27058 & 24235 & 36 \\
\hline Spain & 26044 & 28052 & 32327 & 35306 & 32080 & 23 \\
\hline Sweden & 41042 & 43899 & 50485 & 52632 & 43347 & 6 \\
\hline United Kingdom & 37881 & 40381 & 46191 & 43022 & 35220 & -7 \\
\hline Total & 676410 & 728315 & 850336 & 927859 & 819775 & 21 \\
\hline Source: UN & & & &
\end{tabular}

Source: UN (2012)

The effect of carbon tax on certain industries has also been subject to empirical research.

- In a study of energy intensive industries, 21 OECD countries between 1992 and 2008 revealed that carbon tax had a positive influence on the international competitiveness of energy intensive industries in export countries (Zhao, 2011). An important point to note is that carbon tax has important implications in terms of global competitiveness of economies and even though global competitiveness may not be reduced over the long term by higher energy prices, the short-term effects of a carbon tax may be serious for certain industries (Zhang \& Baranzini, 2004).

- In Sweden, the implementation of carbon tax has had no effect in terms of economic efficiencies in the transport, household and service sectors; however, carbon tax accounted for \$1,6 billion of government revenue in 1995 (Bohlin, 1998). 
- $\quad$ The implementation of excise tax on passenger motor vehicles (based on emission levels rather than engine size) in Ireland is expected to result in a decrease in fiscal revenue by up to half a billion euro in 2025 (Hennessy \& Toll, 2011).

\section{AN EVALUATION OF NATIONAL TREASURY'S CASE FOR CARBON TAX}

Considering the above, within the South African context, it was not disputed that cap-and-trade schemes could achieve the same objectives as carbon taxes. National Treasury did, however, argue that cap-and-trade schemes brought specific challenges to the South African context. These include the i) credibility of emission caps, the allocation of permits and the need for a competitive market to facilitate trading, ii) price uncertainty, iii) the need for new financial regulations and administrative capacity, iv) tax implications, as well as v) the non-transparency of distributional incidence (National Treasury, 2010).

- $\quad$ Firstly, with regard to the credibility of emission caps and the allocation of permits, the EU ETS permit allocations in first phase were greater than verified emissions, which were due to using emission projections before verifiable emissions data became available (Gilbertson \& Reyes 2009). It was argued that if a cap-and-trade scheme is to work in South Africa, it will be critical for caps to be based on verified emissions data. The emissions data in Table 2, for the second phase of the EU ETS, indeed confirms the effectiveness of credible caps in reducing carbon emissions.

- $\quad$ Secondly, with regard to price uncertainty, this is definitely a valid challenge as seen in EU ETS, where prices have moved significantly in response to new information regarding the allocation of allowances (Goldblatt, 2010b). The market structure in which permits are traded are equally important, as in South Africa there is a high concentration of emissions in the energy and fossils fuels sector that will create a challenge to the design of an emissions trading scheme in terms of addressing market power as well as ensuring trading liquidity (Goldblatt, 2010b).

- $\quad$ Thirdly, in terms of the administration of an emission trading scheme, most installations in EU ETS chose between a method of calculation or continuous measurement, with the former being the practical choice (Brohe, 2010). Each member state in the EU ETS is also required to keep a national registry to ensure accurate accounting of all allowances under the Kyoto Protocol (Brohe, 2010). It is clear that any emissions trading scheme in South Africa will require additional administrative resources for both the government and firms alike.

- $\quad$ Fourthly, the tax implications of cap-and-trade can be complicated, especially in the EU ETS, where there has been extensive grandfathering of emission rights (allocating them without charge) (IMF, 2008). Some experts argue that the grandfathered rights should be recorded as tax expenditure as a minimum, opening the issue up for public debate (IMF, 2008). This will present a valid challenge for South African Revenue Service (SARS) and NT if an emissions trading system were to be implemented in South Africa.

- $\quad$ Fifthly, in respect of the challenge of distributional incidence, a study examining the welfare effect of emissions trading under oligopolistic trading conditions found that refunding $10 \%$ of the emission trading proceeds resulted in optimal welfare improvements where such proceeds are reinvested in renewable energy sources (Traber \& Kemfert, 2010). In South Africa, the structure of the energy sector market is oligopolistic (National Treasury, 2010), and provided the proceeds from emissions trading are invested in renewable energy, the challenge may be addressed effectively.

The effects of carbon tax on the competitiveness of industries are positive, and in addition, the carbon tax also increases fiscal revenue, although when replacing another tax, the results may be adverse to the fiscus. The effect of cap-and-trade schemes over the long term on industry is positive, with most EU ETS countries still experiencing positive GDP per capita growth at current prices over a five-year period of the EU ETS.

\section{CONCLUSION}

The objective of this article was to consider the effect of cap-and-trade and carbon tax schemes on sustainable development and to use this information in assessing the National Treasury's decision to implement carbon tax in South Africa. In determining the impact of cap-and-trade and carbon tax on sustainable development, the distinguishing features between both instruments were highlighted. The primary difference is that carbon tax is a 
pricing instrument offering certainty about price but uncertainty about the quantity of emission reductions, whereas a cap-and-trade scheme is a quantity instrument, offering certainty about the quantity of emission reduced but uncertainty about the carbon price.

The studies evaluating the effect of carbon tax on greenhouse gas reduction confirm that the tax has the overall effect of reducing greenhouse gases. These results were obtained from both models predicting the impact of carbon tax on greenhouse gases as well as post-ex results of introducing a carbon tax. In respect of emissions trading, the first phase of the EU ETS showed no decrease in carbon emissions, which was primarily due to permit allocation being based on estimates of carbon emissions rather than verified emissions. However, the second phase of the EU ETS showed a material decline in carbon emissions with caps being based on verified emissions. On a whole, the impact of both market-based instruments on environmental and economically sustainable development is positive. The National Treasury's reasons for not implementing cap-and-trade schemes were explained on the basis of a list of factors that were considered challenging within a South African context. These challenges included the credibility of emission cap, the allocation of permits, the need for a competitive market to facilitate trading, price uncertainty, tax implications, the need for new financial regulations and administrative capacity as well as the nontransparency of distributional incidence.

The significant challenges from a South African context remain a competitive market for trading, price uncertainty, tax implications and administrative capacity. The welfare effect may be positive provided the South African government reinvests proceeds from emissions trading in renewable energy. The credibility of the emission cap and allocation of permits can be addressed by using verifiable emissions as a basis for determining the quantitative limits of carbon emissions and allocating permits based on verifiable emissions rather than grandfathering permits. The decision by the Treasury on a whole is considered rational and acceptable from an economic and environmental perspective.

\section{LIMITATIONS AND FUTURE RESEARCH}

A key limitation of the study is that it does not produce any new empirical insights nor does it necessarily validate any existing empirical insights. Notwithstanding this limitation, the article contribution can be seen in it contrasting evaluation of cap-and-trade schemes as opposed to carbon tax schemes, especially in the context of a developing economy such as South Africa. Although the study has led to theoretical insights regarding the relationship of carbon tax and cap-and-trade schemes on greenhouse gas emissions and economic growth, an empirical study will be necessary to validate the theoretical conclusions arrived at in the study. As far as future research opportunities regarding the impact of carbon tax and cap-and-trade schemes on economic and environmental sustainability, the following may be considered. The third phase of the EU ETS started in 2012 and should end in 2020. The level of allocated permits in the third phase is expected to be even smaller than in the second phase. The impact of a shortfall in permit allocations on carbon leakage, which occurs when there is an increase in carbon dioxide in one country as a result of an emissions reduction by a second country with a strict climate policy could be significant. The ability of multi-national companies operating in countries with stringent climate change policies to shift production processes to other countries with less stringent climate change policies and thereby nullify any emission reductions should be considered in determining the true effectiveness of the EU ETS in the third phase.

\section{AUTHOR INFORMATION}

Suren Pillay is a Chartered Accountant (SA) and works at the Large Business Centre section of the South African Revenue Service (SARS) Kwazulu Natal. Suren is currently a PhD candidate at the North-West University in South Africa's Potchefstroom campus. This article is based on the research conducted for his PhD degree in Taxation.

Professor Pieter W Buys is currently the Research Program Leader at the North-West University (South Africa) and holds two PhDs (Accountancy and Management Accountancy), two Masters Degrees (MComm and MBA), and he is also a US Certified Management Accountant (CMA). Contact: School of Accounting Sciences, North West University, Private Bag X6001, Potchefstroom, 2520, South Africa. E-mail: Pieter.Buys@nwu.ac.za (Corresponding author) 


\section{REFERENCES}

1. Anon. (2006). "Sustainable development. Policy and guide for the EEA (European Economic Area) financial mechanism and the Norwegian financial mechanism." Available: www.eeagrants.org/asset/341/1/341_1.pdf. Date of Access: 10 September 2011.

2. $\quad$ Anon. (2008a). "South Africa's Automotive Industry." Available: http://www.southafrica.info/ business/economy/sectors/automotive-overview.htm. Date of Access: 17 March 2012.

3. Anon. (2008b). "Emissions trading: 2007 verified emissions from EU ETS businesses. European Commission Press Release 23 May 2008." Available: http://europa.eu/rapid/pressReleasesAction.do? reference $=I P / 08 / 787 \&$ format $=H T M L \& a g e d=0 \&$ language $=E N \&$ guiLanguage $=e n$. Date of Access: 30 July 2012.

4. $\quad$ Anon (2010). "Vehicle makers warn carbon tax will impact sales and prices." Available: http://www.engineeringnews.co.za/article/vehicles-makers-warn-carbon-tax-will-impact-sales-2010-02-18. Date of Access: 17 March 2012.

5. Anon. (2012). "Cap-and-Trade Versus Carbon Tax: Two Approaches to Curbing Greenhouse Gas Emissions." Available: http://www.lwv.org/content/cap-and-trade-versus-carbon-tax-two-approachescurbing-greenhouse-gas-emissions. Date of Access: 26 June 2012.

6. Abrell, J. Fayes, A.N. \& Zachmann, G. (2011). "Assessing the impact of the EU ETS using firm level data. 24p. (unpublished)" Available: http://emf.stanford.edu/files/docs/273/Assessing the impact of the EU_ETS using firm level data_Abrell\%26Ndoye\%26Zachmann.pdf. Date of Access: 22 July 2012.

7. $\quad$ Barker, T., Junankar, S., Pollitt, H. \& Summerton, P. (2007). "Carbon leakage from unilateral environmental tax reforms in Europe, 1995 - 2005." Energy Policy, 35(12):6281-6292, December.

8. Belcher, K., Boehm, M. \& Fulton, M. (2003). "An Agroecosystem Scale Evaluation of the Sustainability Implications of Carbon Tax and Carbon Credit Policies." Journal of Sustainable Agriculture, 22(2):75-97, Winter.

9. Bohlin, F. (1998). "The Swedish carbon dioxide tax: effects on biofuel use and carbon dioxide emissions." Biomass and Bioenergy, 15(4/5):283-291, October.

10. Brohe, A. (2010). "Personal carbon trading in the context of the EU Emissions Trading Scheme." Climate Policy, 10 (4):462-476, June.

11. Bruvoll, A \& Larsen, B.M. (2004). “Greenhouse gas emissions in Norway: Do carbon taxes work?" Energy Policy, 32(4):493-505.

12. Clarke, H. (2011). "Some Basic Economics of Carbon Taxes.” The Australian Economic Review, 44(2):123-136.

13. CLC, (2012). "Carbon Leakage: What is it? Policy options for preventing it." Available: http://www.canadianlabour.ca/news-room/publications/carbon-leakage-what-it-policy-options-preventing-it Date of Access: 25 August 2012.

14. Convery, F., Ellerman, D. \& Perthius, C. (2008). "The European Carbon Market in Action: Lessons from the First Trading Period." Journal for European Environmental \& Planning Law, 5(1):215-233. August.

15. Cronje, F. \& Chenga, C.S, (2009). "Sustainable social development in the South African mines." Development Southern Africa, 26(3):416, September.

16. DEAT. (2010). "Kyoto Protocol \& the Clean Development Mechanism." Available: http://www.environment.gov.za/ClimateChange2005/Kyoto Protocol.htm Date of Access: 28 August 2010.

17. $\quad$ Finnern, A. (2010). "Carbon Tax.” Accountancy SA, 12:26-28, December.

18. Gilbertson, T. \& Reyes, O. (2009). "Carbon Trading: How it works and why it fails." Critical Currents. Dag Hammerskjold Foundation. Occasional paper series, 7:9-10, November.

19. Goldblatt, M. \& Davies, G. (2002). "Water, energy and sustainable economic development in South Africa." Development Southern Africa, 19(3):369-387, September.

20. Goldblatt, M. (2010a). "A comparison of emissions trading and carbon taxation as carbon mitigation options for South Africa." (In Winkler, H., Marquaard, A. \& Jooste J., eds. Putting a Price on Carbon: Economic instruments to mitigate climate change in South Africa and other developing countries: Papers read at the Energy Research Centre, University of Cape Town, held in Cape Town on 24 March, 2010. Cape Town. p. 181-195.) 
21. Goldblatt, M. (2010b). "A comparison of emissions trading and carbon taxation in South Africa." Climate Policy, 10(5):511-526. June.

22. Henessy, H. \& Toll, R.S.J. (2011). "The impact of tax reform on new car purchases in Ireland." Energy Policy, 39(11):7059-7067. November.

23. Hintermann, B. (2012). "Pricing emission permits in the absence of abatement." Energy Economics, 34(5):1329-1340. September.

24. IMF see International Monetary Fund.

25. International Monetary Fund. (2008). "The Fiscal Implications of Climate Change.” Available: www.imf.org/ external/np/pp/eng/2008/022208.pdf. Date of Access: 28 July 2010.

26. Keibun, M. (2011). "Modelling the impact of a carbon tax: A trial analysis for Washington State." Energy Policy, 48(2):627-639. September.

27. Kloess, A. \& Muller, M. (2011). "Simulating the impact of policy, energy prices and technological progress on the passenger car fleet in Austria - A model based analysis 2010-2050." Energy Policy, 39 (9):50455062, March.

28. Lin, B. \& Li, X. (2012). "The effect of carbon tax on per capita $\mathrm{CO}_{2}$ emissions." Energy policy, 39(9):5137-5146, September.

29. Mohammed, N. (2011). "Environment and sustainable development in Bangladesh: A legal study in the context of international trends." International Journal of Law and Management, 53(2):89-107.

30. National Treasury. (2010). Discussion Paper for Public Comment: Reducing Greenhouse Gas Emmissions: The Carbon Tax Option. Pretoria: Government Printer. 75p.

31. NAAMSA see National Association of Automobile Manufacturers of South Africa.

32. National Association of Automobile Manufacturers of South Africa. (2011). Quarterly Review of Business Conditions: New Vehicle Manufacturing Industry. Pretoria. 6p.

33. Newport, D., Chesnes, M. \& Lidner, A. (2003). "The environmental sustainability problem ensuring that sustainability stands on three legs." International Journal of Sustainability in Higher Education, 4(4):357363.

34. Nordhaus, W. (2007). "To Tax or Not to Tax: Alternative Approaches to Slowing Global Warming." Review of Environmental Economics and Policy, 1(1):26-44, Winter.

35. OECD see Organisation for Economic Co-operation and Development.

36. Ollila, A. (2012). "The Roles of Greenhouse Gases in Global Warming." Energy \& Environment, 23 (5):781-800. July.

37. Organisation for Economic Co-operation and Development. (1997). "Glossary of Statistical Terms." Available: http://stats.oecd.org/glossary/daspetail.?ID=287. Date of access: 3 July 2011.

38. Pearce, D. (2003). "The social cost of carbon and its policy implications." Oxford Review of Economic Policy, 19(3):362-384. November.

39. Pearson, M. \& Smith, S. (1991). The European Carbon Tax: An Assessment off the European Commission's Proposals. London: The Institute for Fiscal Studies. 62p.

40. Pope, J. \& Owen, A. D. (2009). "Emission trading schemes: potential revenue effects, compliance costs and overall tax policy issues." Energy Policy, 37(11):4595-4603. November.

41. Ren, Z \& Lin, Y. (2001). "Global warming and its astro-causes.” Kybernetes, 30(4):411 - 433.

42. Sathiendrakumar, R. (2003). "Greenhouse emission reduction and sustainable development." International Journal of Social Economics, 30(12):1233-1248.

43. $\quad$ SBS. 2012. "Carbon taxes around the world." Available: http://www.sbs.com.au/news/article/1492651/Factbox-Carbon-taxes-around-the-world. Date of Access: 19 August 2012.

44. Shakya, S., Kumar, S. \& Shrestha, R. (2012). "Co-benefits of a carbon tax in Nepal.” Mitigation and Adaptation Strategies for Global Change. 17(1):77-101.

45. Shepherd, J.G. (2012) Geoengineering the climate: an overview and update. Philosophical Transactions of The Royal Society A Mathematical Physical and Engineering Sciences, 370, (1974), 4166-4175.

46. Shirley, B. (2010). "South Africa: Carbon Tax to Add Thousands to Cars." Business Day, 2 Sep. Available: http://www.businessday.co.za/Articles/Content.aspx?id=119959. Date of access: 28 December 2011.

47. Smithsonian, (2009). "The Political History of Cap and Trade." Available http://www.smithsonianmag.com/science-nature/Presence-of-Mind-Blue-Sky-Thinking.html?c=y\&page=2 . Date of Access: 22 August 2012. 
48. Tietenberg, T. (2003). "The Tradable-permits approach to protecting the commons: Lessons for climate change." Oxford review of Economic Policy, 19(3):403. Winter.

49. Traber, T. \& Kemfert, C. (2010). "Refunding ETS proceeds to spur the diffusion of renewable energies: An analysis based on the dynamic oligopolistic electricity market model EMELIE." Utilities Policy, 19(1):3341. January.

50. UNFCCC see United Nations Framework Convention on Climate Change.

51. United Nations Framework Convention on Climate Change. (2004). "A National Climate Change Response Strategy for South Africa." Available http://unfccc.int/files/meetings/seminar/application/pdf/sem_sup3_south_africa.pdf. Date of Access: 12 September 2010.

52. WWF. (2012). "Carbon tax design options - A discussion document." Available: http://awsassets.wwf.org.za/downloads/carbon_tax_design_options_a discussion_document_final_launch product 1.pdf. Date of access: 19 August 2012.

53. Yamagugchi, K. (2007). "The effect of carbon tax is estimated using the energy demand function which considers the price elasticity of energy." Energy Economics, 29(6):1254-1259. November.

54. Yusuf, R., Noor, Z.Z., Abba, A.H., Hassan, A.A.H. \& Din, M.F.M., 2012. "Methane emission by sectors: A comprehensive review of emission sources and mitigation methods." Renewable and Sustainable Energy Reviews, 16 (7):5059-5070. September.

55. Zhang, Z., \& Baranzini, A. (2004). "What do we know about carbon taxes? An inquiry into their impacts on competitiveness and distribution of income." Energy Policy, 32(4):507-518.

56. Zhao, (2011). "The Study of Effect of Carbon Tax on the International Competitiveness of Energyintensive Industries: An Empirical Analysis of OECD 21 Countries, 1992-2008." Energy Procedia, 5(2011):1291-1302. 